\title{
Application of enzymatic preparations to produce araçá pulp and juice
}

\author{
Ivana Greice SANDRI ${ }^{1 \star}$, Luciani Tastch PIEMOLINI-BARRETO ${ }^{1}$, Roselei Claudete FONTANA ${ }^{2}$, \\ Mauricio MOURA DA SILVEIRA ${ }^{2}$
}

\begin{abstract}
In the present study, the effect of pectinases on the production of pulp and juice of araça and the presence of bioactive compounds were evaluated. An enzyme extract (EE) produced by Aspergillus niger LB-02-SF in solid state fermentation and the commercial enzyme Ultrazym ${ }^{\circledR}$ AFP-L were used in this study. After enzyme treatment with the EE preparation, the extraction yield increased by $23.1 \%$ and viscosity decreased by $42.8 \%$, during pulp maceration. During juice processing, there was an increase of $70.6 \%$ in clarification and a decrease of $72.87 \%$ in turbidity. Higher values of these parameters, 47.7, 69.0, 80.7, and 79.7\%, respectively, were obtained using the Ultrazym ${ }^{\circledR} \mathrm{AFP}-\mathrm{L}$, which also led to a significant increase in the polyphenol content, both in the pulp (24\%) and in the juice (28\%), with a less pronounced effect when the EE was applied (10 and 21\%, respectively). The anthocyanins content in the araçá pulp increased after treatment with the commercial preparation (23\%), and there was no significant increase with the use of EE. The use of Ultrazym ${ }^{\circledR} \mathrm{AFP}-\mathrm{L}$ increased the $\beta$-carotene content by $29.4 \%$ in the fruit pulp, while the treatment with EE did not result in significant changes compared with those of the juice and pulp controls.
\end{abstract}

Keywords: Aspergillus niger; yield; clarification; bioactive compounds.

\section{Introduction}

Brazil is a country with a rich biodiversity of plants (Queiroz et al., 2006; Fiaschi \& Pirani, 2009); however, the number of domesticated native species utilized for fruit production or fruit derived products is still limited. An example of a commercially underexploited native fruit is the araçá (Psidium cattleianum Sabine). The harvest of araçá in Brazil is done through extractivism between February and May. (Drehmer \& Amarante, 2008). This fruit is rich in phenolic compounds, which are positively correlated with antioxidant activity, antimicrobial, and antiproliferative effects, and it contains high levels of anthocyanins and vitamins B and C (Medina et al., 2011).

Like other fruits, araçá has higher sensory quality when harvested ripe; however, it is highly perishable after exposure to room temperature for one or two days (Drehmer \& Amarante, 2008). A practical way to deliver perishable products, such as araçá, to consumers, to increase their shelf life, and to prevent further losses due to ageing is by processing the fruit in the form of pulp or juice (Santos et al., 2007).

The rheological behavior is one of the most important aspects to be considered during fruit processin, not only as a measure of quality, but also to develop projects and evaluate the performance of processes and equipment (Ibarz et al., 1996). Since araçá pulp has high viscosity (Haminiuk et al., 2006), the industrial processing of this fruit must necessarily take into account issues related to rheology.

Several studies have reported that depectinization of juices by enzyme treatment with pectinases is an efficient alternative for this industry (Landbo et al., 2007; Sandri et al., 2011, 2013a). Pectinases act on pectin leading to a decrease in the fluid viscosity, allowing the agglomeration of the particulate matter and the formation of flocks, which can be separated by filtration or centrifugation. This results in a clarified product with higher yield, particularly those that impart flavor and color (Sandri et al., 2013b). Aspergillus niger pectinases are the most widely used in industries because this strain is generally classified as GRAS (Generally Regarded As Safe); therefore, the metabolites produced by this strain can be safely used (Gummadi \& Panda, 2003).

Thus, in the present study, the use of two pectinolytic enzyme preparations, one commercial and one experimental, for the production of araçá pulp and juice was evaluated. The results were evaluated in terms of yield, viscosity, clarification, turbidity, and content of polyphenolic compounds, anthocyanins, and carotenoids.

\section{Material and methods}

\subsection{Production of experimental enzymatic extract}

Aspergillus niger LB-02-SF (University of Caxias do Sul) was used for the production of enzymatic extract (EE) in solid medium. The strain was grown in glycerol-agar medium, at $30{ }^{\circ} \mathrm{C}$ for five days, and then stored at $4{ }^{\circ} \mathrm{C}$.

The medium used in the solid-state process was developed by Fontana et al. (2005) and had the following composition (per $100 \mathrm{~g}$ ): wheat bran (MOINHO NORDESTE, Brazil), $36.6 \mathrm{~g}$; citric pectin (CP KELCO S.A., Brazil), 6.0 g; and salt solution, 
$36.6 \mathrm{~mL}$. The formulation of salt solution was $(\mathrm{g} / \mathrm{L}):\left(\mathrm{NH}_{4}\right)_{2} \mathrm{SO}_{4}$, $4.0 ; \mathrm{MgSO}_{4}, 1.0 ; \mathrm{KH}_{2} \mathrm{PO}_{4}, 2.0 ; \mathrm{FeSO}_{4} \cdot \mathrm{H}_{2} \mathrm{O}, 6.3 \times 10^{-4}, \mathrm{ZnSO}_{4}$, $6.3 \times 10^{-4}, \mathrm{MnSO}_{4}, 1.0 \times 10^{-5}$. Initial moisture content was adjusted with distilled water to reach a concentration of $63 \mathrm{~g}$ of water per $100 \mathrm{~g}$ of medium and the medium was then autoclaved at $1 \mathrm{~atm}$ for 20 minutes. Beaker flasks $(100 \mathrm{~mL})$ with $12 \mathrm{~g}$ of medium were used to obtain the enzymatic extract in solid-state fermentation process. The flasks were inoculated with $A$. niger spores to reach an initial concentration of $1 \times 10^{7}$ spores/L and incubated at $30^{\circ} \mathrm{C}$ in a humidity-saturated environment for 72 hours. The flasks were covered with cotton and gauze. The enzyme extraction from the medium was performed by suspending $2.7 \mathrm{~g}$ of medium in $15 \mathrm{~mL}$ of distilled water $(\mathrm{pH}$ 4) using $125 \mathrm{~mL}$ flasks under reciprocal agitation at $200 \mathrm{rpm}$ at $30^{\circ} \mathrm{C}$. The solutions obtained were centrifuged for 10 minutes at $5000 \mathrm{~g}$. The supernatant was stored at $4{ }^{\circ} \mathrm{C}$ for later analyses (Fontana et al., 2005).

\subsection{Fruit}

The araçá (Psidium cattleianum Sabine) fruits used were harvested in March 2013 in the city of Flores da Cunha, Southern Brazil. The fruits were chosen based on skin color (reddish color) and aspect (low level of mechanical damages). They were selected, carefully washed in running water, and sanitized $\left(6 \mathrm{~mL} / \mathrm{L}\right.$ Pury Vitta ${ }^{\circledR}$ fruit and vegetable disinfectant with $0.96 \mathrm{~g} / 100 \mathrm{~g}$ active chloride) before being processed.

\subsection{Enzymatic treatments}

To obtain the pulp, samples of about $200 \mathrm{~g}$ of fruit (whole fruit) were placed into polythene bags containing the commercial enzyme preparation Ultrazym ${ }^{\circledR} \mathrm{AFP}-\mathrm{L}$ obtained from cultures of $A$. niger and A. aculeatus (Novozymes Latin America LTD, Brazil) or from the EE, diluted in $10 \mathrm{~mL}$ of distilled water; both with total pectinase activity (TPA) of $1 \mathrm{U}$ per gram of fruit. Control samples, in which the enzyme preparations were replaced by distilled water, were prepared for all assays. Controls and treatments were incubated in a thermostatic bath (Certomat WR, B. BRAUN BIOTECH model, Germany) at $50{ }^{\circ} \mathrm{C}$ for 60 minutes, and the enzymatic activity was stopped by cooling to $4{ }^{\circ} \mathrm{C}$ in an ice bath. The pulp was obtained by grinding the fruit in an industrial blender (METVISA, Brazil), and it was then sieved using a 10-mesh sieve to separate the edible pulp from the seeds and insoluble particles. The pulp yield was determined gravimetrically taking into account the mass of the pulp of the control samples and the enzymatically treated samples.

For juice production, $10 \mathrm{~mL}$ of solution from each enzyme preparation (experimental enzyme extract EE and commercial enzyme preparation Ultrazym ${ }^{\circledR}$ AFP-L) under evaluation were added to $50 \mathrm{~mL}$ of pulp contained in $100 \mathrm{~mL}$ beakers to obtain $1 \mathrm{U}$ of TPA per $\mathrm{mL}$ of pulp. The remaining hydrolysis conditions were the same as those used to obtain the pulp. After the treatment, the material obtained was filtered through a Whatman Grade No. 1 filter paper to obtain the juice, which was used to determine the clarification increment and turbidity reduction.

\subsection{Analytical methods}

The endo-PG activity was determined by measuring of the reduction in viscosity of a standard solution of citric pectin (CP KELCO S.A., Brazil) $0.63 \%$ (w/v) in $0.05 \mathrm{M}$ acetate buffer $\mathrm{pH}$ 4.0. The analysis was carried out using $3.2 \mathrm{~mL}$ of sample diluted in $14.8 \mathrm{~mL}$ of citric pectin solution, and the reaction was carried out at $30{ }^{\circ} \mathrm{C}$ for 30 minutes. Thereafter, viscosity variations were measured using a Brookfield DV-II+ viscometer (BROOKFIELD ENGINEERING, USA). One endo-PG unit was defined as the quantity of enzyme which causes a $50 \%$ reduction in the solution viscosity under standardized conditions (Gainvors et al., 2000).

Protein content in the araçá fruits was determined by Lowry procedure (Lowry et al., 1951) adapted by Pinelo et al. (2010). Briefly, $0.5 \mathrm{~mL}$ of $\mathrm{CuSO}_{4} \cdot 5 \mathrm{H}_{2} \mathrm{O}(10 \mathrm{~g} / \mathrm{L})$ was mixed with $50 \mathrm{~mL}$ of $10 \mathrm{~g} / \mathrm{L}$ of $\mathrm{Na}_{2} \mathrm{CO}_{3}-\mathrm{KNa}$-tartrate, and $1.0 \mathrm{~mL}$ of the resulting solution was mixed with $0.1 \mathrm{~mL}$ of a suspension prepared with $1 \mathrm{~g}$ of crushed fruit, to which $49 \mathrm{~mL}$ of water were added. The solutions obtained were then centrifuged for 5 minutes at 10000 g. After 10 minutes, $0.1 \mathrm{~mL}$ of Folin Ciocalteu reagent was added to the reaction. Absorbance was measured at $660 \mathrm{~nm}$ after 30 minutes of incubation. The protein content was expressed as bovine serum albumin (BSA) equivalents in $\mathrm{mg} / \mathrm{g}$ of fresh fruit.

In order to determine the pectin content in araçá, polysaccharides were extracted from samples prepared with $5 \mathrm{~g}$ of crushed fruit suspended in $245 \mathrm{~mL}$ of water acidified with citric acid to $\mathrm{pH} 2.5$, under reflux in a condensation system operated at $97^{\circ} \mathrm{C}$ for 30 minutes. Pectin was precipitated by alcohol-juice treatment 2:1 (v/v). The mixture of solvent and precipitate was stirred for 10 minutes and then left to rest for one hour to allow pectin flotation. After this procedure, the pectic substances remain at surface of the alcohol/water mixture, and thus it is easier to remove them in a quantitative way. The floating pectin coagulate was filtered through a cheesecloth, rinsed with $95^{\circ} \mathrm{GL}$ alcohol, and pressed. The pressed pectin was dried to constant weight at $55^{\circ} \mathrm{C}$ and cooled in a desiccator; the yield was calculated on a dry weight basis (initial weight of the sample) (Canteri-Schemin et al., 2005).

The araça $\mathrm{pH}$ was measured on suspension of crushed fruit in de-ionized water ( $1 \mathrm{~g}$ plus $49 \mathrm{~mL}$, respectively) using a digital pH meter (Horiba F series, Model F21).

Viscosity of the araçá pulp was measured in $20 \mathrm{~mL}$ samples at $30{ }^{\circ} \mathrm{C}$ using a Brookfield DV-II + viscometer (Brookfield, USA) (Aguiló-Aguayo et al., 2010).

The yield of the enzymatically treated araçá pulps was determined gravimetrically considering the mass of the untreated control pulps. The degree of viscosity and yield were expressed as percentage of viscosity or yield, calculated with the results of the control samples of every assay.

The clarification of araçá juice was evaluated following each treatment using a spectrophotometer (AURORA INSTRUMENTS, USA) by adding absorbance results at 420,520 and $620 \mathrm{~nm}$, as proposed by Rangana (1977) with modifications.

The turbidity of araçá juice was evaluated following each treatment using a spectrophotometer (AURORA 
INSTRUMENTS, USA) at $540 \mathrm{~nm}$ (Chatterjee et al., 2004). The degree of clarification and turbidity were expressed as percentage of clarification or turbidity, calculated with the results of the control samples of every assay.

Total phenols in araçá pulp and juice were determined by the Folin-Ciocalteu procedure (Singleton \& Rossi, 1965), as follows: $1 \mathrm{~mL}$ of 10 fold diluted Folin-Ciocalteu reagent was added to $0.2 \mathrm{~mL}$ of 1:10 diluted sample and incubated at room temperature (approximately $25^{\circ} \mathrm{C}$ ); after 1 minute, $0.8 \mathrm{~mL}$ of $\mathrm{Na}_{2} \mathrm{CO}_{3}$ solution $(75 \mathrm{~g} / \mathrm{L})$ was added and the mixture was shaken, and after two hours absorbance was measured at $765 \mathrm{~nm}$. The phenolic content was expressed as catechin equivalents in $\mathrm{mg} / \mathrm{mL}$.

The total anthocyanin was determined according to Francis (1982). A $3 \mathrm{~g}$ sample was homogenized with a solution of $30 \mathrm{~mL}$ (ethanol 95\% and $\mathrm{HCl} 1.5 \mathrm{~N}, 85: 15, \mathrm{v} / \mathrm{v}$ ) and stored for $12 \mathrm{~h}$ at $4{ }^{\circ} \mathrm{C}$. The mixture was filtered and the residue was washed with the extraction solution until complete removal of pigments. The volume was completed to $100 \mathrm{~mL}$ with the extraction solution, and the mixture was allowed to stand for $2 \mathrm{~h}$ at room temperature $\left(28 \pm 2{ }^{\circ} \mathrm{C}\right)$. The absorbance of each sample was measured at the $535 \mathrm{~nm}$. The total anthocyanin content was calculated using the absorption coefficient of 982 , corresponding to Cyanidin 3-glucoside in ethanol/HCl (Zanatta et al., 2005).

The carotenoids in the araçá pulp and juice were determined using the method of Talcott \& Howard (1999), with modifications. Two $\mathrm{mL}$ of sample were homogenized in the dark with $25 \mathrm{~mL}$ of an acetone/ethanol (1:1) solution containing $250 \mathrm{mg} / \mathrm{L}$ of BHT (2.6-di-tert-butyl-4-methyl phenol). The samples were centrifuged for 20 minutes at 15,000 rpm, and the supernatant was used to determine the total amount of carotenoids. Then, spectrophotometric reading was performed at $470 \mathrm{~nm}$ using a mixture of acetone-ethanol $(1: 1 \mathrm{v} / \mathrm{v})$ as a blank. The concentration of total carotenoids was calculated by comparison against a curve constructed with the $\beta$-carotene standard and expressed in $\mathrm{mg}$ of $\beta$-carotene per $100 \mathrm{~mL}$ of sample.

\subsection{Statistical analysis}

The statistical analyses were performed by analysis of variance (one-way ANOVA) and the Tukey's test, with significance level below $5 \%(\mathrm{p}<0.05)$.

\section{Results and discussion}

In order to define the best conditions to obtain fruit pulp and juice using pectinolytic enzyme preparations, the composition of the fruit must be taken into account. Proteins present in the fruit can affect the activity of these enzymes since they interact with phenolic compounds forming complexes that are difficult to remove. The polyphenols contribute to haze formation due to interactions with proteins through mechanisms involving prior polymerization or oxidation, leading to the formation of polymeric complexes with high molecular-weight that precipitate out as haze. The amount of haze formed depends on the concentrations of protein and polyphenol (Siebert et al., 1996).The analyses in the araçá fruits evaluated showed that protein concentration was low, around $0.96 \mathrm{mg} / \mathrm{g}$ of fresh fruit, compared with that found by Pinelo et al. (2010).

Other components of araça that must be quantified are the pectic substances. Pectic substances are a group of polysaccharides in plant cell walls and some mucilages (Yapo, 2011); they form a physical barrier that hinders the extraction of juice present in the fruit. In addition, pectic substances are the main components that influence viscosity and turbidity of juices. In the present study, it was found that araça contains a significant amount of pectin (about $7.7 \mathrm{~g} / 100 \mathrm{~g}$ of fresh fruit), compared with that of other fruits, for example: butia palm fruit $(3.44 \mathrm{~g} / 100)$, blueberry $(3.77 \mathrm{~g} / 100 \mathrm{~g})$, and Isabel grape variety (4.56 g/100 g) (Sandri et al., 2011).

Enzyme activity is also influenced by the $\mathrm{pH}$ of the fruit pulp and juice. The $\mathrm{pH}$ of fresh araçá was 3.47. This $\mathrm{pH}$ value favors the activity of pectinolytic enzymes present in the EE Sandri et al. (2011) found that the pectinolytic activity in this extract had its peak in the range of 3.0-4.0. With regard to the commercial preparation Ultrazym ${ }^{\circledR} \mathrm{AFP}-\mathrm{L}$, according to the manufacturer, the optimal $\mathrm{pH}$ is $2.8-3.8$, a range favorable for the activity of the enzymes present in this preparation. Table 1 shows the results of the effects of enzymatic treatment after the soaking steps to obtain the fruit pulp and treatment to obtain the juice.

When the EE preparation was used, lower results of yield and a decrease in pulp viscosity were obtained compared to those found with Ultrazym ${ }^{\circledR}$ AFP-L. When conducting the treatments, the two enzyme preparations were diluted to have the same total pectinolytic activity. Thus, the difference in yield observed and the decrease in viscosity can be attributed to the presence of higher activities of other hydrolytic enzymes, such as cellulases, amylases, and xylanases present in the commercial preparation, suggesting the degradation of fruit cell wall (Sandri et al., 2011).

The yield and the decrease in viscosity of the pulp are related parameters since the degradation of the cell wall occurs with consequent release of water and polysaccharides of lower molecular weight, which causes a decrease in the viscosity and an increase of water in solution (pulp).

As can be seen in Table 1, there is a direct relationship between the decrease in turbidity and the increase in clarification for all juices. The increase in clarity and decrease in turbidity in the juices was similar in both enzymatic treatments, i.e., with the use of Ultrazym ${ }^{\circledR}$ AFP-L and EE.

The formation of visually perceptible haze is considered a significant product defect. Haze particles in clear beverages can

Table 1. Effects of enzymatic treatments on the production of pulp and juice of araçá in comparison with blank samples.

\begin{tabular}{lcc}
\hline \multicolumn{1}{c}{ Parameters } & Ultrazym ${ }^{\circledR}$ AFP-L & EE \\
\hline Pulp yield increment (\%) & $47.7 \pm 4.3$ & $23.1 \pm 1.7$ \\
Pulp viscosity reduction (\%) & $69.1 \pm 2.3$ & $42.8 \pm 1.7$ \\
Juice clarification increment (\%) & $80.7 \pm 4.0$ & $79.7 \pm 4.3$ \\
Juice turbidity reduction (\%) & $70.6 \pm 2.3$ & $72.8 \pm 1.7$ \\
\hline
\end{tabular}

EE - enzimatic extract produced by Aspergillus niger LB-02-SF. 
originate from processing defects (such as fragments of filter media or adsorbents) or from inorganic or organic particles formed in the package (Fleet \& Siebert, 2005).

The suspended matter in juices, responsible for turbidity, consist of cell fragments deriving directly from pulp tissue, pectin, starch, phenol polymerization, or not entirely dissolved components (Lea, 1995). When there is no enzymatic treatment of the pulp, the colloidal substances remain suspended leading to increased turbidity of the juices. Pectin acts as a protective colloid in order to hinder the precipitation of these impurities. These results can be compared to those found by Sandri et al. (2013a), who evaluated the experimental enzyme extract produced by A. niger LB23 in blueberry and apple juices and observed an increase in the clarification by levels between 40 and $90 \%$.

Table 2 shows the values of polyphenols, anthocyanins, and carotenoids in the araçá pulp and juice after enzymatic treatments and in the control samples. The growing interest in the exploitation of these bioactive compounds has encouraged studies on the application of enzymes to hydrolyze the cell wall components. Enzymes such as pectinases, cellulases, and hemicellulase can hydrolyze the cell wall components, which results in higher extraction yields of bioactives (Chandini et al., 2011; Puri et al., 2012; Kapasakalidis, et al., 2009).

When comparing the levels of phenolic compounds, anthocyanins, and carotenoids present in the control pulps with those of the enzymatically treated pulps, especially those treated with Ultrazym ${ }^{\circledR}$ AFP-L, it can be observed that the enzymes positively contributed to the removal of these compounds.

Enhancement of polyphenol bio-activities by enzyme reactions has also been reported by different authors (Chamorro et al., 2012; Puri et al., 2012). Accordingly, more pigment (anthocyanin) was extracted during the vinification process, when enzymes were applied on grape skin (PiemoliniBarreto et al., 2014). In another example, the extraction of

Table 2. Polyphenols, anthocyanins, and $\beta$-carotene contents in araçá pulp and juice after enzymatic treatments.

\begin{tabular}{|c|c|c|}
\hline \multirow[t]{2}{*}{ Treatment } & \multicolumn{2}{|c|}{ Polyphenols (mg catechin / 100mL) } \\
\hline & Pulp & Juice \\
\hline Control & $359.6 \pm 13.9^{c}$ & $333.7 \pm 11.3^{c}$ \\
\hline Ultrazym ${ }^{\circledR}$ AFP-L & $447.8 \pm 15.4^{\mathrm{a}}$ & $402.5 \pm 17.5^{\mathrm{b}}$ \\
\hline $\mathrm{EE}$ & $395.1 \pm 3.3^{\mathrm{b}}$ & $381.5 \pm 9.0^{\mathrm{b}}$ \\
\hline \multirow[t]{2}{*}{ Treatment } & \multicolumn{2}{|c|}{ Anthocyanins (mg cyanidin-3-glucoside/100mL) } \\
\hline & Pulp & Juice \\
\hline Control & $4.83 \pm 0.3^{b}$ & $4.75 \pm 0.47^{\mathrm{b}}$ \\
\hline Ultrazym ${ }^{\circledR}$ AFP-L & $5.96 \pm 0.85^{\mathrm{a}}$ & $3.86 \pm 0.76^{c}$ \\
\hline $\mathrm{EE}$ & $5.03 \pm 0.54^{\mathrm{ab}}$ & $4.05 \pm 0.93^{\mathrm{bc}}$ \\
\hline \multirow[t]{2}{*}{ Treatment } & \multicolumn{2}{|c|}{$\beta$-carotene $(\mu \mathrm{g} / \mathrm{mL})$} \\
\hline & Pulp & Juice \\
\hline Control & $0.51 \pm 0.04^{\mathrm{b}}$ & $0.46 \pm 0.03^{\mathrm{b}}$ \\
\hline Ultrazym ${ }^{\circledR}$ AFP-L & $0.66 \pm 0.05^{\mathrm{a}}$ & $0.51 \pm 0.03^{\mathrm{b}}$ \\
\hline $\mathrm{EE}$ & $0.54 \pm 0.02^{\mathrm{b}}$ & $0.49 \pm 0.02^{\mathrm{b}}$ \\
\hline
\end{tabular}

carotenoids from marigold flower or tomato skin (Barzana et al., 2002; Dehghan-Shoar et al., 2011) indicates that enzymes can also be useful for the extraction of bioactive compounds from other plant sources.

After the second enzymatic treatment to produce clarified juice, different responses were obtained according to the compound analyzed. As for the polyphenol content, there was a significant increase compared to that of the control juice, while the levels of $\beta$-carotene found were statistically similar to those of the control juice. With regard to the anthocyanin concentration, there was a significant decrease in the treatment with Ultrazym ${ }^{\circledR}$ AFP-L when compared to that of the control juice.

Some commercial enzyme preparations exhibit secondary enzymatic activities that can change the profile of phenolic compounds (Pinelo et al., 2006). These enzymes may also be present in the experimental extract, but in smaller amounts once these enzymes were not concentrated. An example of this effect is the degradation of anthocyanins by glycosidases, as reported by Pricelius et al. (2009).

Based on the levels of phenolic compounds, anthocyanins, and carotenoids in the araça pulp and juice, it is evidenced the need of using enzymes in the processing of araçá fruit. However, the use of enzymatic treatments to obtain bioactive compounds requires further investigation on enzymatic degradation and extraction of these compounds due to the composition of the cell wall and activity of different enzymes.

\section{Conclusions}

The results of this study demonstrate the application potential of the enzyme treatment to obtain araçá pulp and juice. The enzyme treatment positively influenced the process in terms of increased yield, decreased viscosity and turbidity, and an increase in clarity, especially with the use of the commercial enzyme preparation Ultrazym ${ }^{\circledR}$ AFP-L. With regard to phenolic compounds, anthocyanins, and carotenoids, it was found that the enzyme treatments favored, or at least it did not impair, the results in terms of the amount of these compounds in the araçá pulp. On the other hand, as for the araça juice, the data obtained are not that conclusive, and the results varied for the different compounds with or without enzymes.

The results obtained for the enzyme extract produced by A. niger LB-02-SF are still preliminary, and therefore, the results of some parameters such as enzyme concentration, temperature, and reaction time can be optimized. The experimental extract should also undergo concentration and purification treatments, and the formulation that includes hydrolytic enzymes from different sources, especially cellulases, amylases, and xylanases, should be defined as commonly done for commercial preparations such as that evaluated this study.

\section{Acknowledgements}

The authors acknowledge the financial support from the Fundação de Amparo à Pesquisa do Estado do Rio Grande do Sul (FAPERGS), Coordenação de Aperfeiçoamento de 
Pessoal de Nível Superior (CAPES), Conselho Nacional de Desenvolvimento Científico e Tecnológico ( $\mathrm{CNPq})$, and Universidade de Caxias do Sul (UCS).

\section{References}

Aguiló-Aguayo, I., Soliva-Fortuny, R., \& Martín-Belloso, O. (2010). Color and viscosity of watermelon juice treated by highintensity pulsed electric fields or heat. Innovative Food Science \& Emerging Technologies, 11(2), 299-305. http://dx.doi.org/10.1016/j. ifset.2009.12.004.

Barzana, E., Rubio, D., Santamaria, R. I., Garcia-Correa, O., Garcia, F., Ridaura Sanz, V. E., \& López-Munguía, A. (2002). Enzymemediated solvent extraction of carotenoids from marigold flower (Tagetes erecta). Journal of Agricultural and Food Chemistry, 50(16), 4491-4496. http://dx.doi.org/10.1021/jf025550q. PMid:12137466

Canteri-Schemin, M. H., Fertonani, H. C. R., Waszczynskyj, N., \& Wosiacki, G. (2005). Extraction of pectin from apple pomace. Brazilian Archives of Biology and Technology, 48(2), 259-266. http:// dx.doi.org/10.1590/S1516-89132005000200013.

Chamorro, S., Viveros, A., Alvarez, I., Vega, E., \& Brenes, A. (2012). Changes in polyphenol and polysaccharide content of grape seed extract and grape pomace after enzymatic treatment. Food Chemistry, 133(2), 308-314. http://dx.doi.org/10.1016/j. foodchem.2012.01.031.

Chandini, S. K., Rao, L. J., Gowthaman, M. K., Haware, D. J., \& Subramanian, R. (2011). Enzymatic treatment to improve the quality of black tea extracts. Food Chemistry, 127(3), 1039-1045. http://dx.doi.org/10.1016/j.foodchem.2011.01.078. PMid:25214094

Chatterjee, S., Chatterjee, S., Chatterjee, B. P., \& Guha, A. K. (2004). Clarification of fruit juice with chitosan. Process Biochemistry, 39(12), 2229-2232. http://dx.doi.org/10.1016/j.procbio.2003.11.024.

Dehghan-Shoar, Z., Hardacre, A. K., Meerdink, G., \& Brennan, C. S. (2011). Lycopene extraction from extruded products containing tomato skin. International Journal of Food Science \& Technology, 46(2), 365-371. http://dx.doi.org/10.1111/j.1365-2621.2010.02491.x.

Drehmer, A. M. F., \& Amarante, C. V. T. (2008). Post harvest preservation of red strawberry-guavas as affected by maturity stage and storage temperature. Revista Brasileira de Fruticultura, 30(2), 322-326. http://dx.doi.org/10.1590/S0100-29452008000200009.

Fiaschi, P., \& Pirani, J. R. (2009). Review of plant biogeography studies in Brazil. Journal of Systematics and Evolution, 47(5), 477-496. http:// dx.doi.org/10.1111/j.1759-6831.2009.00046.x.

Fleet, C. F., \& Siebert, K. J. (2005). Effect of illumination intensity on visual perception of turbidity. Food Quality and Preference, 16(6), 536-544. http://dx.doi.org/10.1016/j.foodqual.2004.12.001.

Fontana, R. C., Salvador, S., \& Silveira, M. M. (2005). Influence of pectin and glucose on growth and polygalacturonase production by Aspergillus niger in solid-state cultivation. Journal of Industrial Microbiology \& Biotechnology, 32(8), 371-377. http://dx.doi. org/10.1007/s10295-005-0004-0. PMid:16059783

Francis, F. J. (1982). Analysis of anthocyanins. In P. Markakis (Ed.), Anthocyanins as food colors (cap. 7, pp. 182-205). New York: Academic Press.

Gainvors, A., Nedjaoum, N., Gognies, S., Muzart, M., Nedjma, M., \& Belarbi, A. (2000). Purification and characterization of acidic endo-polygalacturonase encoded by the PGL1-1 gene from Saccharomyces cerevisiae. FEMS Microbiology Letters, 183(1), 131-135. http://dx.doi.org/10.1111/j.1574-6968.2000.tb08946.x. PMid:10650215
Gummadi, S. M., \& Panda, T. (2003). Purification and biochemical properties of microbial pectinases [Review]. Process Biochemistry, 38(7), 987-996. http://dx.doi.org/10.1016/S0032-9592(02)00203-0.

Haminiuk, C. W. I., et al (2006). Influence of temperature on the rheological behavior of whole araçá pulp (Psidium cattleianum sabine). LTW - Food Science and Technology, 39(4), 427-431.

Ibarz, A., Gonçalvez, C. A., \& Explugas, S. (1996). Rheology of clarified passion fruit juices. Fruit Processing, 6(8), 330-333.

Kapasakalidis, P. G., Rastall, R. A., \& Gordon, M. H. (2009). Effect of a cellulase treatment on extraction of antioxidant phenols from black currant (Ribes nigrum L.) pomace. Journal of Agricultural and Food Chemistry, 57(10), 4342-4351. http://dx.doi.org/10.1021/jf8029176. PMid:19354247

Landbo, A.-K., Kaack, K., \& Meyer, A. S. (2007). Statistically designed two step response surface optimization of enzymatic prepress treatment to increase juice yield and lower turbidity of elderberry juice. Innovative Food Science \& Emerging Technologies, 8(1), 135142. http://dx.doi.org/10.1016/j.ifset.2006.08.006.

Lea, A. G. H. (1995). Zumo de manzana. In P. R. Ashurst (Ed.), Producción y envasado de zumos y bebidas de frutas sin gás (pp. 146-189). Espana: Acribia.

Lowry, O. H., Rosebrough, N. J., Farr, A. L., \& Randall, R. J. (1951). Protein measurement with the Folin phenol reagent. The Journal of Biological Chemistry, 193(1), 265-275. PMid:14907713.

Medina, A. L., Haas, L. I. R., Chaves, F. C., Salvador, M., Zambiazi, R. C., da Silva, W. P., Nora, L., \& Rombaldi, C. V. (2011). Araçá (Psidium cattleianum Sabine) fruit extracts with antioxidant and antimicrobial activities and antiproliferative effect on human cancer cells. Food Chemistry, 128(4), 916-922. http://dx.doi.org/10.1016/j. foodchem.2011.03.119.

Piemolini-Barreto, L. T., Zacaria, J., Delamare, A. P. L., Antonio, R. V., \& Echeverrigaray, S. (2014). Variation in phenolic compounds, anthocyanins, and color in red wine treated with enzymatic extract of Kluyveromyces marxianus. World Journal of Microbiology \& Biotechnology, 30(5), 1541-1547. http://dx.doi.org/10.1007/s11274013-1577-9. PMid:24347085

Pinelo, M., Arnous, A., \& Meyer, A. S. (2006). Upgrading of grape skins: Significance of plant cell-wall structural components and extraction techniques for phenol release. Trends in Food Science \& Technology, 17(11), 579-590. http://dx.doi.org/10.1016/j.tifs.2006.05.003.

Pinelo, M., Zeuner, B., \& Meyer, A. S. (2010). Juice clarification by protease and pectinase treatments indicates new roles of pectin and protein in cherry juice Turbidity. Food and Bioproducts Processing, 88(2-3), 259-265. http://dx.doi.org/10.1016/j.fbp.2009.03.005.

Pricelius, S., Murkovic, M., Souter, P., \& Guebitz, G. M. (2009). Substrate specificities of glycosidases from Aspergillus species pectinase preparations on elderberry anthocyanins. Journal of Agricultural and Food Chemistry, 57(3), 1006-1012. http://dx.doi.org/10.1021/ jf803131t. PMid:19191672

Puri, M., Sharma, D., \& Barrow, C. J. (2012). Enzyme-assisted extraction of bioactives from plants. Trends in Biotechnology, 30(1), 37-44. http://dx.doi.org/10.1016/j.tibtech.2011.06.014. PMid:21816495

Queiroz, L. P., Rapini, A., \& Giulietti, A. M. (2006). Towards greater knowledge of the Brazilian semi-arid biodiversity. Brasília: Ministério da Ciência e Tecnologia.

Rangana, S. (1977). Manual of analysis of fruit and vegetable products. New Delhi: McGraw-Hill.

Sandri, I. G., Lorenzoni, C. M. T., Fontana, R. C., \& Silveira, M. M. (2013a). Use of pectinases produced by a new strain of Aspergillus niger for the enzymatic treatment of apple and blueberry juice. LWT - Food Science and Technology, 51(2), 469-475. http://dx.doi. org/10.1016/j.lwt.2012.10.015. 
Sandri, I. G., Piemolini-Barreto, L. T., \& Fontana, R. C. (2013b). Enzymes in food processing. In P. S. Panesar \& S. S. Marwaha (Eds.), Biotechnology in agriculture and food processing: opportunities and challenges (pp. 331-355). India: Taylor \& Francis Group.

Sandri, I. G., Fontana, R. C., Barfknecht, D. M., \& Silveira, M. M. (2011). Clarification of fruit juices by fungal pectinases. LWT - Food Science and Technology, 44(10), 2217-2222. http://dx.doi.org/10.1016/j. lwt.2011.02.008.

Santos, M. S., Petkowicz, C. L. O., Wosiacki, G., Nogueira, A., \& Carneiro, E. B. B. (2007). Caracterização do suco de araçá vermelho (Psidium cattleianum Sabine) extraído mecanicamente e tratado enzimaticamente. Acta Scientiarum Agronomy, 29(5), 617-621. http://dx.doi.org/10.4025/actasciagron.v29i5.737.

Siebert, K. J., Troukhanova, N. V., \& Lynn, P. Y. (1996). Nature of polyphenol-protein interactions. Journal of Agricultural and Food Chemistry, 44(1), 80-85. http://dx.doi.org/10.1021/jf9502459.
Singleton, V. L., \& Rossi, J. A. (1965). Colorimetry of total phenolics with phosphomolybdic-phosphotungstic acid reagent. American Journal of Enology and Viticulture, 16(3), 144-158.

Talcott, S. T., \& Howard, L. R. (1999). Phenolic autoxidation is responsible for color degradation in processed carrot puree. Journal of Agricultural and Food Chemistry, 47(5), 2109-2115. http://dx.doi. org/10.1021/jf981134n. PMid:10552504

Yapo, B. M. (2011). Pectic substances: from simple pectic polysaccharides to complex pectins. A new hypothetical model. Carbohydrate Polymers, 86(2), 373-385. http://dx.doi.org/10.1016/j. carbpol.2011.05.065.

Zanatta, C. F., Cuevas, E., Bobbio, F. O., Winterhalter, P., \& Mercadante, A. Z. (2005). Determination of anthocyanins from camu-camu (Myrciaria dubia) by HPLC-PDA, HPLC-MS, and NMR. Journal of Agricultural and Food Chemistry, 53(24), 9531-9535. http://dx.doi. org/10.1021/jf051357v. PMid:16302773 